Prof. dr. sc. Sulejman Kendić ${ }^{1}$

Mr. sc. dr. med. Samir Porić, viši ass. ${ }^{2}$

\title{
INTERFERENCIJA HRANE I LIJEKOVA
}

\section{Sažetak}

Interferencija hrane i lijekova je uzajamno slabljenje, jačanje ili poništenje djelovanja lijeka ili nutrijenata iz hrane. Lijekovi imaju puno veci $i$ znaćajniji utjecaj na ishranu i prehrambeni status osoba, nego što hrana utječe na djelotvornost lijekova. Gotovo svaki lijek, više ili manje, utječe na metabolizam pojedinih nutritivnih tvari. Interakcija hrane i lijekova obično se javlja kroz tri različite vrste mehanizama: hrana može povećati stopu ili opseg apsorpcije lijeka, smanjiti stopu ili opseg apsorpcije ili imati izravan farmakološki učinak.

Ishrana je značajan faktor održavanja tjelesnog $i$ duševnog zdravlja $i$ radne sposobnosti ljudi. Hrana, odnosno njeni sastojci - proteini, masti, ugljikohidrati, mineralne supstance $i$ vitamini), imaju važne (dolje navedene) fiziološke funkcije:

1. plastična uloga, tj. izgradnja ćelija i tkiva i proizvodnja tjelesnih tečnosti,

2. oslobadanje toplote, tj. kalorija potrebnih za energetske rashode organizma,

3. biohemijska regulisanja metabolizma materija u organizmu.

Odnos hrane i lijekova, i obrnuto, poznat je već od najstarijih historijskih razmatranja. Danas, kad farmaceutska industrija postaje sve jača i kad na raspolaganju imamo mnoštvo najrazličitijih lijekova različitog hemijskog sastava, taj odnos postaje sve značajniji i izraženiji. Dugo je već poznato da pojedini lijekovi koče, a drugi pospješuju i pojačavaju iskoristivost $i$ razgradnju hrane. Isto tako nam je poznato da pojedine vrste hrane mogu umanjiti ili pojačati efektivnost djelovanja pojedinih vrsta lijekova. Hrana,

\footnotetext{
${ }^{1}$ Visoka zdravstvena škola u Bihaću.

${ }^{2}$ Visoka zdravstvena škola u Bihaću.
} 
dakle, može utjecati na apsorpciju, metabolizam $i$ ekskreciju lijeka, a jednako tako lijek može utjecati na digestiju (varenje hrane), metabolizam, apsorpciju i ekskreciju hranjivih sastojaka.

Ključne riječi: hrana, lijek, interakcija, interferencija

\section{UVOD}

Hrana može da utječe na apetit, apsorpciju hranjivih tvari, metabolizam te apsorpciju i izlučivanje lijeka iz organizma. U ishrani postoji reciprocitet djelovanja hrane na lijek i djelovanja lijeka na hranu. Hrana može imati interakcije sa lijekovima, a kao rezultat mogu nastati ozbiljne reakcije u organizmu koje ugrožavaju, oštećuju zdravlje. Bioraspoloživost hrane/lijeka u funkciji su od apsorpcije i interakcija tokom prvog metaboličkog prolaska kroz organizam (first-pass metabolism). Pritom lijekovi i hrana mogu uzrokovati više oblika međusobnih interakcija.

Moguće su tri osnovne forme interakcija:

1. aditivne,

2. sinergističke $\mathrm{i}$

3. antagonističke.

Antagonističke interakcije su u svakom slučaju nepovoljne, a poželjne mogu biti u slučaju kad hrana pomaže resorpciju i bioiskoristivost lijeka. Neki sastojci iz hrane mogu pojačavati efekt lijeka, i to aditivna ili sinergistička forma interakcije. To podrazumijeva da hrana može uticati na apsorpciju, distribuciju, metabolizam i ekskreciju lijeka. Istovremeno, lijek može uticati na digestiju, metabolizam, apsorpciju i ekskreciju hranjivih sastojaka. U slučaju politerapije i polipragmazije (koliko simptoma toliko $i$ lijekova), vjerovatnoća ovih događaja se povećava, pogotovo što se sa hranom unose brojne biološki aktivne komponente koje se metaboliraju slično lijekovima.

\section{CILJ RADA}

Teorijski, na osnovu naučnih spoznaja za indikaciono područje djelovanja lijeka, pokazati kako izvršiti odabir hrane u ishrani 
(hranidbenih tvari), tako da se smanji negativna interferncija lijeka na hranu - hrane na lijek.

\section{DISKUSIJA/RASPRAVA}

Kod uzimanja određenih lijekova treba obratiti pažnju na odabir hrane jer ona može djelovati na pojedine sastojke lijeka i stvoriti korisne, ali i neželjene, pa čak i opasne posljedice po organizam.

Postoje neka opća pravila kod korištenja hrane i lijekova kao što su:

- uzimanje lijekova sa puno vode,

- ne miješanje hrane sa lijekovima,

- ne miješanje lijekova sa toplim pićima i

- ne uzimanje lijekova sa alkoholnim pićima.

Postoji i pravilo fastinga (fast eng. post), što podrazumijeva neunošenje hrane sat prije i dva sata poslije uzimanja lijekova. Isto tako, ima lijekova koje je bolje uzeti zajedno s jelom jer budu brže ili sporije resorbirani, ovisno o svrsi.

Kod utjecaja lijeka na hranu i hrane na lijek važni su slijedeći faktori: hemijski sastav, doza i ekspozicija nekog lijeka, hemijska kompozicija i struktura hrane koja se unosi u organizam, kao i starosna dob pojedinca, spol, tjelesna masa, volumen tijela, nutricijski status, općezdravstveno stanje, status u odnosu na poroke - pušenje, kahva, alkohol, droga i sl. Svi faktori pojedinačno ili u kombinaciji mogu utjecati na djelovanje lijekova, kao i na iskoristivost nutrienata u hrani.

Hrana utječe na stimulaciju sekrecije u probavnom (digestivnom) traktu, mijenja se kiselost hrane, što može zakočiti apsorpciju lijeka, a time i njegovo djelotvorno svojstvo. Pojedini sastojci u hrani mogu da za sebe vežu lijek i čine kompleks - time se gubi djelotvornost lijeka. Poznato je da hrana usporava ili sprječava apsorpciju aspirina kao najčešće upotrebljavanog lijeka. Kalcij iz mlijeka na sebe veže tetracikline (antibiotik širokog spektra) i sprječava apsorpciju molekule tog lijeka. Hranidbene tvari u hrani imaju to svojstvo da se u crijevima natječu za 
apsorpciju sa drugim molekulama, pa i sa djelotvornim supstancijama lijeka.

Pojedine grupe lijekova mogu da ometaju unos hrane preko različitih mehanizama svojih nuspojava. Poznati su lijekovi koji utječu na apetit (tzv. anoreksici, npr. amfetamin, pripravci digitalisa, narkotici: kodein, meperidin, morfin itd.), nesteroidni antireumatici (aspirin, ibubrufen, naprokesin), antacidi koji dugotrajnom upotrebom mogu izazvati oštećenje bubrega i trovanje sa aluminijom i magnezijom u čijem se sastavu nalaze ovi elementi (aluminij i magnezij: aluminijum hidroksid, magnezijum hidroksid, magnezijum oksid, magnezijum citrat). Lijekovi za anksioznost (uznemirenost) mogu da povećaju apetit, prouzrokuju nastanak debljine, opstipacije (zatvor), suhoću u ustima, da izazovu proljev kod nekih osoba. Uzimanje lijekova iz grupe citosatika (lijekovi za maligne bolesti), izaziva promjene kao što su smanjenje apetita, mučnine, povraćanje, stvaranje afti u usnoj duplji, što u konačnici izaziva smanjen unos hrane. Laksansi - lijekovi koji se koriste za pražnjenje crijeva, ometaju apsorpciju hranjivih tvari (osobito vitamina, kalcija), dolazi do malapsorpcije bitnih nutrijenata.

Lijekovi mogu u organizmu da mijenjaju aktivnost pojedinih enzima i tako utječu na razgradnju i apsorpciju hranidbenih tvari. $\mathrm{Na}$ nivou bubrega lijek može da ometa reapsorpciju nutrijenata ili premještanje nutrijenta sa proteina, koji mu služi kao nosač, npr. diuretici (skupina lijekova koji uzrokuju povećano izlučivanje urina) koče reapsoprciju natrija i kalija u bubrežnim kanalićima (tubulima).

Slijedeći lijekovi: glukokortikoidi, tijazidski diuretici, etakrinska kiselina, furosemid, nikotinska kiselina, brojni kontraceptivi, entiepileptici) povisuju razinu glukoze u krvi, a time i povećano lučenje inzulina iz gušterače čija se endokrina funkcija može iscrpiti ili smanjiti i dovesti do pojave šećerne bolesti (diabetes mellitus). Vitamini imaju najveću interferenciju sa lijekovima. Pušenje i alkohol snižavaju razinu $\mathrm{B}_{12}$ i $\mathrm{C}$ vitamina, dok antiepileptici (lijekovi koji se koriste u sprječavanju epileptičkih napadaja) snižavaju razinu $\mathrm{D}$ vitamina. 
Farmaceutske tvornice prave pripravke (minerale, vitamine itd.) kao suplemente hrani.

U suplementaciji:

- vitamin A, preporučuje se kod hiperkeratoza (psorijaze, akni itd.),

- nikotinska kiselina (niacin) - za snižavanje lipidnih komponenti,

- vitamin C - za akutne upale respiratornog sistema (prehlade), stresna stanja,

- piridoksin $\left(\mathrm{B}_{6}\right)$, daje se trudnicama koje imaju mučninu, nagon za povraćanje, nuspojave radio-hemoterapije,

- preparati joda - uzimaju se kao dobar ekspektorans, jod se koristi za jodiranje soli za prevenciju gušavosti, kretenizma.

\section{Interakcije neke hrane sa lijekovima}

- Masna hrana usporava pražnjenje želuca mnogo jače nego proteinska ili ugljikohidratna hrana. Stoga će, u slučaju konzumiranja masnije hrane, lijek biti duže izložen djelovanju pepsina (enzim želuca) i hlorovodonične kiseline, nego kad bi taj isti lijek bio uzet između dva obroka. Lijekovi (npr. antibiotici) koji su osjetljiviji na djelovanje hlorovodonične kiseline, mogu biti puno prije razgrađeni nego stignu u tanko crijevo kako bi se apsorbirali, pa se stoga njihovo djelovanje time može značajno umanjiti. Nasuprot tome, postoje lijekovi kojima ovakav tretman pogoduje (npr. grizeofulvin - lijek za gljivice), pa se djelotvornost lijekova time pospješuje.

- Biljna vlakna, a posebno pektin, usporavaju apsorpciju većine lijekova, te im tako odlažu vrijeme djelovanja - osbito za digoksin (jedan od lijekova za srčane bolesnike) i acetaminofen (popularan protiv raznih vrsta bolova).

- Hrana bogata proteinima može imati, slično kao i masna hrana, pozitivan ili negativan učinak, ovisno o vrsti lijeka. Neki lijekovi, ako se uzmu s hranom bogatom proteinima, se mnogo bolje apsorbiraju (npr. 
propranolol, tzv. srčani beta-blokator), a neki puno slabije (npr. metildopi i levodopi, lijek za povišeni krvni tlak).

- Kuhano ili pečeno povrće, npr. luk, može povećati fibrinolitični učinak pojedinih lijekova (npr. varfarina), dok tamnozeleno povrće, zbog toga što je bogato vitaminom K, koči hipoprotrombinemijski učinak oralnih antikoagulansa, lijekova koji sprječavaju zgrušavanje krvi (varfarin, pelentan, heparin i sl.). Tamno lisnato povrće poput kelja, brokule, blitve i zelene salate crvenih listova, prepuno je vlakana, važnih vitamina i hranjivih tvari, uključujući i vitamin $\mathrm{K}$ koji je važan antioksidans koji pomaže u jačanju kostiju i potiče rad mozga. Problem je u tome što je taj isti vitamin ujedno i koagulant te potiče zgrušavanje krvi.

- Mlijeko i mliječni proizvodi svojim sadržajem kalcija mogu kočiti apsorpciju tetraciklinskih antibiotika. Pojedine vrste sireva (npr. camambert, chedar, parmezan itd.) mogu kočiti djelovanje antidepresivnih lijekova, što je posebno izraženo u slučaju lijekova baziranih na djelovanju monoaminooksidaza. Takvo ometanje prvenstveno je izazvano djelovanjem aminokiseline tiamin, koju, osim u pojedinim vrstama sireva, možemo pronaći i u namirnicama kao što su fermentirani mliječni proizvodi, bakalar, feferoni, jetra pilića, pića koja duže stoje (npr. vino) itd.

- Kofeinski napici (kahva, čaj, coca-cola i sl.) mogu u kombinaciji s neuroleptičnim lijekovima (flufenazin, haloperidol, droperidol i dr.) spriječiti njihovu apsorpciju i terapijsko djelovanje. Djelovanje kofeinskih napitaka i namirnica ujedno se negativno odražava ako se konzumiraju lijekovi na bazi teofilina (pripravka za liječenje astme). Rezultat spomenute kombinacije biti će povećanje količine metilksantinskih spojeva u tijelu, a kao posljedica - toksično djelovanje ksantinskih spojeva.

- Alkohol se ne preporučuje ni u jednoj kombinaciji s lijekovima.

- Citrusi ili Agrumi i sokovi agruma mogu zbog visokog sadržaja kalcija (osobito grejp) dolaziti u interakciju sa lijekovima koji blokiraju kalcijeve kanale (nifedipine, procardia, verapamil i sl.). Sok naranče ne bi se smio 
konzumirati zajedno s antacidima (lijek za smanjenje kiselosti u želucu), zbog sadržaja aluminija jer može pospješiti apsorpciju istog koji je po organizam često toksičan.

\section{ZAKLJUČCI}

1. Proučiti uputstvo o lijeku, osobito o interakciji sa hranom;

2. Biljna vlakna, a posebice pektin, usporavaju apsorpciju većine lijekova;

3. Mlijeko i antibiotici - kao posljedica javlja se usporena apsorpcija lijeka, što za posljedicu ima slabiji terapeutski učinak antibiotika;

4. Pojedine vrste sireva (chedar, parmezan) mogu kočiti djelovanje antidepresivnih lijekova;

5. Namirnice bogate kalijem (banane, rajčice, krompir) ne bi trebalo konzumirati u većim količinama kad se koristi diuretik koji štedi kalij, jer dolazi do prevelikog nakupljanja tog minerala $(\mathrm{K}+)$ u organizmu;

6. Kod uzimanja antihipertenziva (lijekova za regulaciju krvnog tlaka) svakako treba obratiti pažnju na količinu unesene soli;

7. Utjecaj kahve, čaja i gaziranih napitaka na lijekove propisane kod astme i bronhitisa - ti lijekovi otežavaju metabolizam kofeina, koji, zbog duljeg zadržavanja u organizmu, ubrzava srčani ritam i pretjerano stimulira središnji živčani sistem. Bronhodilatatori (lijekovi koji šire dišne cijevi) na bazi teofilina su osjetljivi na djelovanje ugljikohidrata (kruha, riže, tjestenine);

8. Grejp nije dobar odabir za osobe koje, zbog dijagnosticirane hiperholesterolemije, dobivaju propisanu terapiju statinima (lijekovi za smanjenje masnoće u krvi). Isto vrijedi i za one koji koriste imunosupresore (kod autoimunih bolesti) i lijekove kod hipertenzivnog stanja (povišenog krvnog tlaka). 


\section{Literatura}

1. Heaney, M. L., Gardner, J. R., Karasavvas, N. i sur. (2008.) Vitamin C antagonizes the cytotoxic effects of antineoplastic drugs. Cancer Res. 68, 80318038.

2. Slain, D., Amsden, J. R., Khakoo, R. A. i sur. (2005.) Effect of high-dose vitamin $C$ on the steady-state pharmacokinetics of the protease inhibitor indinavir in healthy volunteers. Pharmacotherapy. 25, 165-170.

3. Dammann, H. G., Saleki, M., Torz, M., Schulz, H.U., Krupp, S., Schuerer, M., Timm, J., Gessner, U. (2004.) Effects of buffered and plain acetylsalicylic acid formulations with and without ascorbic acid on gastric mucosa in healthy subjects. Aliment. Pharmacol. Ther. 19, 367-374.

4. Živković R. (2002.) Dijetetika. Zagreb: Medicinska naklada, 370-378.

5. Kuo, S. M., Lin, C. P., Morehouse, H. F. (2001.) Dihydropyridine calcium channel blockers inhibit ascorbic acid accumulation in human intestinal Caco-2 cells. Life Sci. 68, 1751-1760.

6. Ćatovoć, S., Kendić, S., Ćatović, A. (2000.) Higijena ishrane sa dijetetikom (univerzitetski udžbenik) Sarajevo: Medicinski fakultet u Sarajevu.77-80.

7. Bassenge, E., Fink, N., Skatchkov, M., Fink, B. (1998.) Dietary supplement with vitamin C prevents nitrate tolerance. J. Clin. Invest. 102, 67-71.

\section{Internetske stranice:}

1. http://www.oktal-pharma.ba/bs/content/display/103/

2. http://www.ordinacija.hr/zdravi-tanjur/hrana-kao-lijek/

3. http://www.zzjzpgz.hr/nzl/19/hrana.htm

4. http://hranomdozdravlja.com/?do=interakcija

5. http://www.plivazdravlje.hr/aktualno/clanak/2074/Interakcija-hrane-i-lijekova 
Sulejman Kendić, PhD Samir Porić, MA

\section{INTERFERENCE BETWEEN FOOD AND MEDICATION}

\section{Abstract}

Interference food and drug is weakening, strengthening or canceling the effects of the drug or nutrients from food. Medications have much larger and more significant impact on nutrition and nutritional status of people than the effect foods have on the efficacy of drugs. Almost every medication more or less affects the metabolism of certain nutritional substances.

Interaction of food and medication usually occures through three different mechanisms: food can increase the rate and extent of absorption of the drug, it can reduce the rate or extent of absorption or have a direct pharmacological effect.

Nutrition is an important factor in maintaining physical and mental health and working ability of people. Food or its ingredients (proteins, fats, carbohydrates, vitamins and mineral substances) have important physiological functions listed below:

1. Plastic role, ie construction of cells and tissues and the production of body fluids.

2. Heat release, tj. meaning calories is energy expenditure required for the organism.

3. Biochemical regulation of the metabolism of substances in the body.

The relationship of food and medicine, and vice versa, has been known since the earliest historical considerations. Today, when the pharmaceutical industry is becoming stronger, and when there is a multitude of different medications of different chemical composition available, this relationship becomes even more significant and more pronounced.

It has long been known that certain drugs inhibit, while others promote and enhance the usability and the breakdown of food. It is also known that certain foods may reduce or boost the effectiveness of the action of certain types of medications. Food may therefore affect the absorption, metabolism and excretion of the drug, and just as the medication may affect digestion (digestion of food), metabolism, excretion and absorption of nutrients.

Keywords: food, drug interactions, interference 
الأستاذ الدكتور سليمان كينديتش ` والمعيد سامر بوريتش؛

\section{التداحل بين الأغذية والأدوية}

\section{الخلاصة}

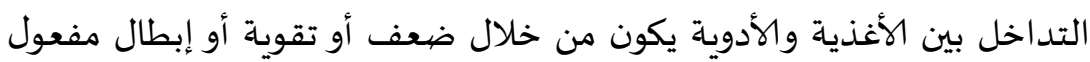

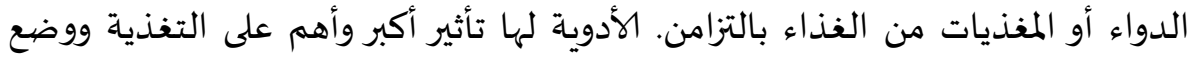

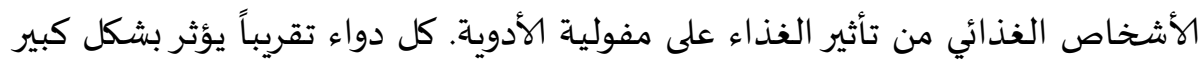
أو صغير على أيض بعض المواد الفذ المن تائر الفذاء علية.

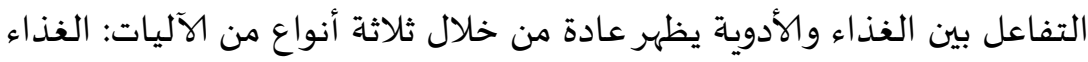

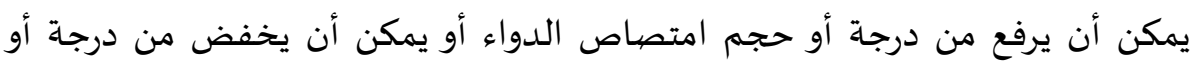

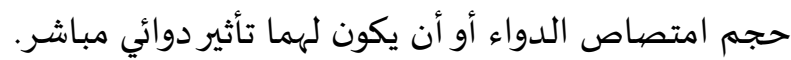

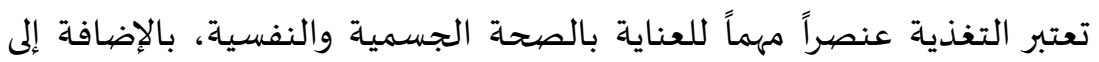

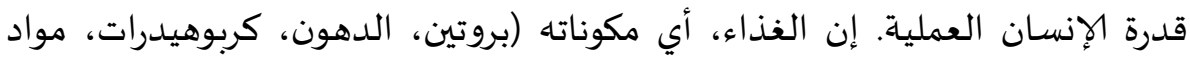

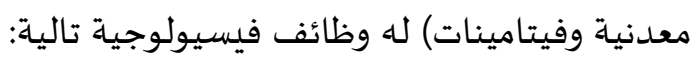

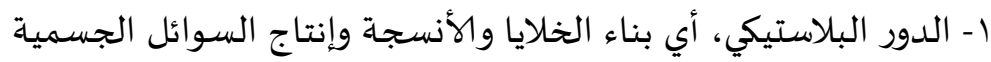

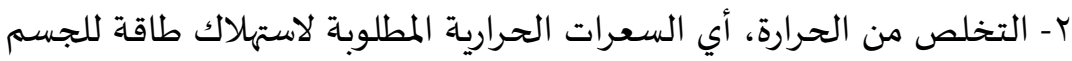

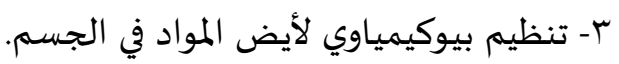

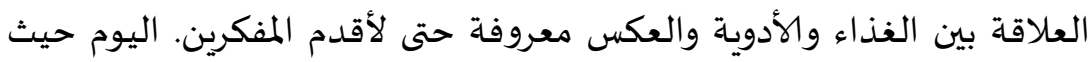

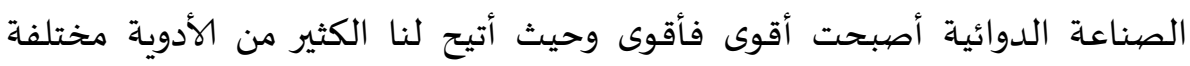
المكونات الكيمياوية، فإن تلك العلاقة تصبح أكثر أهميةً وظهوراً.

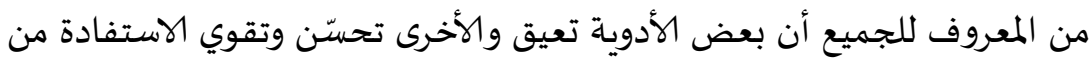

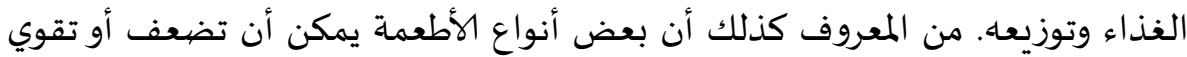

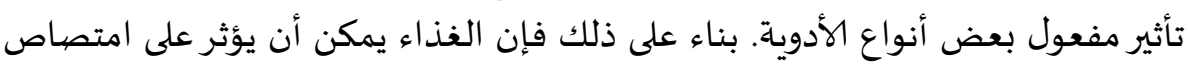

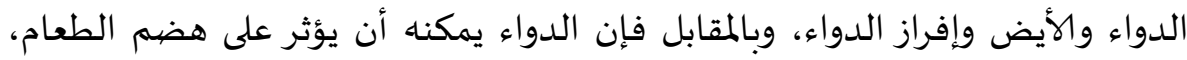
الأيض، امتصاص الطعام وإفراز العناصر الفراز الغذائية.

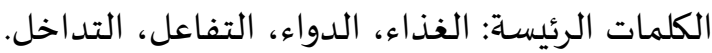

